EDUKACJA MIĘDZYKULTUROWA

2013, nr 2

ISSN 2299-4106

TOMAsz SosNOwsKI

\title{
Kompetencje do komunikacji międzykulturowej w aspekcie tradycyjnej wielokulturowości regionu i procesów migracyjnych
}

\section{Supraśl, 13-14 września 2012 roku}

W dniach 13-14.09.2012 roku odbyła się w Supraślu konferencja naukowa pod hasłem „Kompetencje do komunikacji międzykulturowej w aspekcie tradycyjnej wielokulturowości regionu i procesów migracyjnych", zorganizowana przez Katedrę Edukacji Międzykulturowej kierowaną przez prof. zw. dr. hab. Jerzego Nikitorowicza oraz Zakład Pedagogiki Społecznej Wydziału Pedagogiki i Psychologii Uniwersytetu w Białymstoku, kierowanego przez dr. hab. Mirosława Sobeckiego, prof. UwB.

Celem tego spotkania naukowego był namysł i rozważania prowadzone wokół zagadnień dotyczących kompetencji do komunikacji międzykulturowej, które stanowią istotny element życia mieszkańców ziemi podlaskiej ze względu na procesy migracyjne i wielokulturowość miejsca. Organizatorzy tego spotkania zaproponowali dyskusję wokół kilku kwestii:

- Edukacja międzykulturowa - edukacja dialogu.

- Kompetencje do komunikacji międzykulturowej w kontekście tradycyjnej wielokulturowości regionu i procesów migracyjnych - prezentacja raportu z badań Grantu KBN.

- Komunikacja międzykulturowa jako wyzwanie edukacyjne.

- Przestrzenie dialogu międzykulturowego.

Tematyka obrad plenarnych wyznaczyła także zakres rozważań w dwóch sesjach problemowych:

- Szkoła a kompetencje do komunikacji międzykulturowej.

- Środowisko społeczne a kompetencje do komunikacji międzykulturowej.

Tematyka obrad plenarnych poświęcona była analizie i diagnozie aktualnych zjawisk i procesów społecznych, z uwzględnieniem zróżnicowania środowiska życia człowieka, poszukiwano odpowiedzi dotyczących i związanych $\mathrm{z}$ dylematami kształtowania (się) tożsamości międzykulturowej. Przyjęte ramy tematyczne konferencji znalazły swoje pełne odzwierciedlenie zarówno 
pierwszego, jak i drugiego dnia podczas obrad plenarnych, w dyskusjach oraz autorskich narracjach jej uczestników. Zaproszeni Goście podczas obrad plenarnych i w czasie dyskusji w ramach sesji problemowych poszukiwali m.in. odpowiedzi na pytania: Jak prowadzić dialog międzykulturowy? Jak prowadzić interakcje? Jak rozwiązywać problemy dzisiejszego świata w kontekście zróżnicowania kulturowego? Interesującym głosem w prowadzonej dyskusji było wystąpienie prof. zw. dr. hab. Andrzeja Sadowskiego, który zaprezentował uczestnikom spotkania teorie modernizacji i kultury, przeprowadził analizę skutków społecznych procesów modernizacyjnych oraz zwrócił uwagę na uwarunkowania dialogu międzykulturowego i nadużywanie kategorii naród do wyjaśniania zjawisk współczesnego świata.

Istotnym elementem konferencji była prezentacja raportu z badań Grantu KBN. Prof. zw. dr hab. Jerzy Nikitorowicz wprowadził uczestników w problematykę badań, natomiast pozostali uczestnicy zespołu badawczego ukazali poszczególne zmienne i ich znaczenie w prowadzonych badaniach.

Prof. dr hab. Mirosław Sobecki zaprezentował zmienną zależną - kompetencje, które stanowią wypadkową czterech wymiarów:

- wiedzy o odmienności kulturowej regionu,

- reakcji na sytuacje związane z obecnością odmienności kulturowej,

- pozycji na kontinuum etnocentryzm-relatywizm,

- samooceny postaw badanego wobec odmienności kulturowej.

Dr Dorota Misiejuk ukazała następujące zmienne: umiejętności jednostki (świadomość potrzebnych kompetencji) i społeczny standard wielokulturowości. Dr Jolanta Muszyńska przedstawiła związki między zmienną zależną - kompetencje do komunikacji międzykulturowej - a zmiennymi niezależnymi: środowiskiem szkolnym, zamieszkania, rodzinnym, społecznością lokalną i ich znaczeniem dla badanych. Dr Tomasz Bajkowski dokonał analizy znaczenia następujących zmiennych: typ rodziny pochodzenia, wykształcenie rodziców, aktywność zawodowa rodziców, posiadanie rodzeństwa, deklaracja badanych dotycząca jakości relacji z poszczególnymi członkami ich rodziny, deklaracje dotyczące stylu funkcjonowania rodziny pochodzenia badanych. Prof. dr hab. Wioleta Danilewicz z kolei skupiła się na aspekcie odnoszącym się do procesów migracyjnych i przedstawiła zależności pomiędzy poziomem kompetencji do komunikacji społecznej a wyjazdami badanych za granicę, stosunkiem migrantów wobec cudzoziemców, stosunkiem migrantów z rodziny wobec cudzoziemców. 
Prowadzone dyskusje prowadzone w polu edukacji międzykulturowej stały się zachętą do dalszych eksploracji naukowych. Całość spotkania zakończyła się wspólną deklaracją Uczestników konferencji podkreślającą potrzebę następnych spotkań i dyskursów podczas kolejnej - XII już konferencji naukowej. 